今月は、Nature の論説記事から、“Cheap IVF needed"

というタイトルの記事を取り上げます。IVFとは in vitro

fertilization の略で、「体外受精」のことです。体外受精などの

不妊治療法は、一般に普及したとはいっても、非常に高額な費

用がかかるのが現状です。とりわけ、アフリカの貧困地域にお

いては、手の届かない技術といっても過言ではないでしょう。
アフリカの一部の地域では、子どもに恵まれない女性が悲惨 な境遇に追いやられています。こうした女性たちを社会的に救 うためにも、安価な不妊治療法の研究開発が求められています が、誤った認識 (false perceptions)」のためになかなか進 まないようです。どのような「誤った認識」があるのかに着目 して、記事を読んでみましょう。

Editorial

語数 : 603 words 分野: 医療技術·社会

Nature 442, 958 | doi:10.1038/442958a; Published online 30 August 2006

\title{
Cheap IVF needed
}

http://www.nature.com/nature/journal/v442/n7106/full/442958a.html

False perceptions are hindering access to new research on in vitro fertilization.

1. In the nearly three decades since the arrival of the world's first test-tube baby in 1978, some two million children have been born using in vitro fertilization (IVF). Today, the technique is more popular than ever - but it remains out of reach for many who want it.

2. This is particularly the case in sub-Saharan Africa, where up to one-third of couples are infertile, causing untold misery for millions of women. Fertility treatments are available in private clinics in several countries in the region, but are far too expensive for most people. A number of scientists are now working to make IVF much cheaper and more accessible, and have already come up with some promising alternatives.

3. But ideas for such methods cannot change lives while they remain stuck on the drawing board, and these developments have yet to be validated in clinical trials. The lack of resources, money, awareness and political will combine to stop them getting off the ground. If this is to change, the issue of infertility needs to be pushed higher up the international agenda.

4. Perhaps the biggest obstacle is the widespread, but false, perception that infertility isn't a pressing problem in poor African countries. The region also faces daunting challenges of coping with HIV, tuberculosis and malaria. Many argue, understandably, that fighting these should take priority over infertility, which is not directly lifethreatening.

5. But this argument underestimates the devastating social, economic and personal burden of being childless in many poor societies - a burden that mainly falls on women. They are usually blamed for infertility and can be ostracized and assaulted by their families, even driven to suicide or killed. By supporting the development of low-cost IVF, governments can help make such treatments more widely available.

6. Another frequently heard argument holds that it is inappropriate to prioritize treating infertility in countries that are already struggling to support their fast-growing populations. But the 1948 UN Universal Declaration of Human Rights states: "Men and women of full age, without any limitation due to race, nationality or religion, have the right to marry and to found a family." In cases where parents are unable to have children, this ought to imply the right to access to fertility treatments.

7. Too many women in Africa are deprived of the right to an education, freedom from abuse, and access to decent health care and contraception. As well as being desirable in its own right, the education and empowerment of women has 
been shown to be a critically important factor in slowing the high birth rate that critics of fertility treatments in Africa say they are concerned about.

8. Raising the status of women and broadening access to contraception, particularly condoms, would also help to control the sexually transmitted diseases that are the main causes of infertility in sub-Saharan Africa. The crippling social taboos surrounding childlessness also need to be challenged. But changing age-old prejudices is going to take a great deal of time and concerted effort by governments and by pressure groups such as Chipo Chedu, a Harare-based trust established by Betty Chishava, a Zimbabwean woman cast out of her home for failing to bear children.

9. In the meantime, the scientific and medical community can play its part by creatively questioning whether exotic new equipment and state-of-the-art drug therapies are necessary for safe and effective fertility treatments. Some scientists argue that much of this is dispensable and is largely driven by the affluent end of the fertility market. Indeed, it would be a nice twist if low-cost fertility treatments designed to help impoverished African couples could one day make IVF affordable for less-well-off couples in rich countries too.

\section{Words and phrases}

リード false perceptions : 「誤った認識、誤った理解」

2. untold misery : 「いうにいわれぬ苦しみ」 untold は「数や量が膨大で数え切れない」という意味だが、 misery のような抽象名詞を修飾する場合は、「計り知れない」 「際限のない」と訳される。

3. stuck on the drawing board : 「計画段階で立ち往生し ている」

drawing board は「製図板」のことだが、比ゆ的に「設 計段階」「計画段階」という意味で用いられることも多い。 stuck は、何かに引っかかって前に進めないこと。

3. getting off the ground : $\ulcorner($ 物事が)うまくスタートすること」

4. pressing problem : 差し迫った問題」「緊急の問題」

4. daunting challenges : $「$ 気後れするような難題」 daunt「他人をひるませる、気力をくじく」に由来する daunting が、challenge を修飾している。

5. ostracized : 「追放される」「排斥される」

もともとは古代ギリシャの陶片追放制度（ostracism）にお ける追放を説明する言葉。

\section{Topics Chipo Chedu とは?}

Chipo Chedu はジンバブエの言葉で our gift の意味。設立者 である Betty Chishava は、子どもに恵まれなかったために家 を追い出されて、家族や親戚からも差別や迫害を受けた経験が ある。Chipo Cheduは、女性が経済的に自立できるよう講習 会を開いたり、不妊に対する正しい知識を身につけるためのワー クショップを開いたりして、女性の社会的地位の向上を目指し た活動を行っている（詳しくは、Helen Pilcher, Nature 442， 975-977 の News Feature 参照)。

\section{Science key words}

タイトル IVF : (in vitro fertilization の略)「体外受精」

リード in vitro はラテン語で in glass、つまり「(試験) 管内で」 の意味。対照的に、in vivoは in the living thing、つま り「生体内で」のこと。日本での体外受精による出産は 1983 年に初めて成功し、以来その数は増え続けている。 日本産科婦人科学会の調査によると、2004 年には年間 約 1 万 8000 人、1986 年の調査開始以来の累積出生児 数は約 13 万 6000 人に上っている。

2. fertility treatments : 「不妊治療」 この場合の fertility は、 treatment とあわせて使われ ているので、infertility と同様に「不妊」と訳す。また、 不妊治療を専門とするクリニックは、fertility clinic とも infertility clinic ともよばれる。

4. HIV : (human immunodeficiency virus の略)「ヒト 免疫不全ウイルス、エイズウイルス」

4. tuberculosis : (略 : TB)「結核 (症)」

7. contraception : 「避妊 (法)」

9. sexually transmitted diseases : (略 : STD)「性行 為感染症」ヒトが性行為によって感染する病気の総称。 梅毒、淋病、クラミジア感染症などがある。

6. argument holds that: 主語が人や組織ではなく、 argument、consensus, opinion、theoryといった場 合には、「<主語 $>$ は〜のような内容である」という訳にす るとすっきりする。

7. in its own right: いろいろな意味があるが、ここでは「そ れ自体で」の意味。

8. concerted effort: 「協調的な取り組み」 名詞の concert は「一致」「協力、協調」という意味で、「コ ンサート、演奏会」もこの流れに沿っている。

8. cast A out of B : 「A（人）をB（場所）から追い出す」 名詞 outcast は、追い出された者のことで、「仲間外れ」「の け者」その他の訳語がある。

9. state-of-the-art : 「最先端の、最高技術水準の」

9. the affluent end : 「富裕層」

affluent はrich よりもフォーマルな表現。end を使った用 例としては、high-end「高性能品」「高級品」がある。

9. twist : 「予想外の展開」「意外な展開」

9. impoverished : 「貧困した」 poorの類語だが、「貧困な状態や弱い状態にさせられた」 というニュアンスがある。 
Nature 442, 958 | doi:10.1038/442958a; Published online 30 August 2006

\section{必要とされる安価な体外受精}

http://www.nature.com/nature/journal/v442/n7106/full/442958a.html

誤った認識が体外受精に関する新しい研究の活用を妨げている。

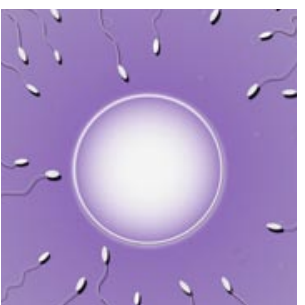

1. 世界初の試験管ベビーが誕生した 1978 年以来、ほぼ 30 年間に約 200 万人の子どもが体外受精（IVF）で生まれて いる。今日、この技術は、かつてない普及をみせているが、 それを必要としつつも利用できない人々も数多くいる。

2. 特にこの傾向が強いのがアフリカのサハラ以南で、夫婦 全体の最大 3 分の 1 が不妊である。そのため、数百万人 の女性がいうにいわれぬ苦しみを味わっている。不妊治 療は、この地域の数か国の私立診療所で行われているが、 ほとんどの人々にとっては高すぎて手が出ない。現在多 くの研究者が、体外受精のコストを大幅に抑えて、利用 しやすくするための研究に取り組んでおり、既にいくつ かの有望な方法が考案されている。

3. ところが、そのような方法のアイデアがあっても、計画 段階で立ち往生していては多くの人々の人生を変えるこ とはできない。新たに開発された体外受精法は、これか ら、その有効性を臨床試験で評価しなければならないの だ。各種資源や資金の不足、人々の意識の低さ、そして 政治的意志の欠如が積み重なると、安価な体外受精法は 軌道には乗らない。この状況を変えるには、不妊問題を 優先順位の高い国際的な課題に押し上げる必要がある。

4. もしかすると、アフリカの貧困国では不妊問題が緊急課 題ではないという誤った認識が世間に広まっていること が最大の障害なのかもしれない。この地域は、HIVや結 核、マラリアに対処するという困難な課題も抱えている。 不妊は直接命にかかわる問題ではないため、前述の疾患 と闘うことのほうが優先順位は高いはずだと主張する者 も多く、その点は理解できる。

5. しかし、この主張は、多くの貧困社会にあって子どもに恵 まれないことが圧倒的に大きな社会的、経済的、個人的な 重荷となることを過小評価している。そして、この重荷を 背負うのは主に女性なのである。通常、不妊は女性が悪い からだとされ、家族や親戚から追放されたり、暴行を受け たりし、場合によっては自殺に追い込まれたり殺害された りすることもある。各国政府は、安価な体外受精法の開発 を支援することで、その普及をさらに促進できる。
6. 急増する国民の生活を支えることにすら苦しんでいる諸 国で、不妊治療を優先させることは不適切だという主張 も頻繁に耳にする。しかし、1948 年の国連世界人権宣 言には、「成年の男女は、人種、国籍または宗教によるい かなる制限をも受けることなく、婚姻し、かつ家族をつ くる権利を有する」と定められている。子どもに恵まれ ない夫婦の場合には、この条項から不妊治療を受ける権 利を導き出せるはずである。

7. 教育を受ける権利や虐待からの自由、そして適正な医療 を受け避妊する権利を奪われた女性が、アフリカには極 めて多い。女性の教育と権利拡大は、それ自体が望まし いだけでなく、アフリカでの不妊治療に批判的な論者が 懸念する高い出生率を抑制する、極めて重要な要素であ ることが明らかになっている。

8. 女性の地位を高め、避妊法、特にコンドームを利用しや すくすることは、アフリカのサハラ以南で不妊症の主な 原因となっている性感染症を防止するうえでも役に立つ。 子どもができないことをめぐって壊滅的なダメージを与 えるような社会的タブーも問題にする必要がある。しか し、昔からの偏見を変えるには、長い時間、そして政府 や「ChipoCheduトラスト」といった圧力団体による 協調的な取り組みが必要となるだろう。このトラストは、 ジンバブエのハラーレに本部があり、子どもができなかっ たことで家庭から追い出されたジンバブエの女性 Betty Chishava が創立した。

9. その一方で科学者や医師は、新型の風変わりな装置や最 先端の薬物療法が、安全で効果的な不妊治療にとって必 要なのかどうかを独創的に見直すことで、その役割を果 たすことができる。装置や薬剤の多くは、なくても困る わけではなく、主に不妊治療市場における富裕層のため に開発されたと主張する科学者もいる。もしアフリカの 貧困家庭の夫婦を救うために低コストの不妊治療法を開 発することで、体外受精が富裕国の比較的低所得の人々 にも利用しやすくなれば、それはすてきな想定外の展開 といえるだろう。 